\title{
Plexippoides flavescens (O. Pickard-Cambridge, 1872) and Menemerus marginatus (Kroneberg, 1875), new records for Pakistan (Aranei: Salticidae)
}

\author{
Plexippoides flavescens (O. Pickard-Cambridge, 1872) \\ и Menemerus marginatus (Kroneberg, 1875), \\ новые находки дмя Пакистана (Aranei: Salticidae)
}

\section{Tobias Bauer ${ }^{1}$, Mario Freudenschuss ${ }^{2}$, Arno Grabolle ${ }^{3}$ Т. Бауер ${ }^{1}$, М. Фрёйденщюс ${ }^{2}$ А. Грабомле ${ }^{3}$}

\author{
${ }^{1}$ Hattenbachweg 12, D-70599 Stuttgart, Germany. E-mail: tobias_bauer@hotmail.de; the corresponding author. \\ ${ }^{2}$ Gutenhofnerstraße 13, AU- 4300 St. Valentin, Austria. \\ ${ }^{3}$ Am Horn 13b, D-99425 Weimar, Germany.
}

KEY WORDS: jumping spiders, new records, South Asia, distribution.

КЛЮЧЕВЫЕ СЛОВА: пауки-скакунчики, новые находки, Южная Азия, распространение.

ABSTRACT. The present work provides two new spider records for the fauna of Pakistan: Plexippoides flavescens (O. Pickard-Cambridge, 1872) and Menemerus marginatus (Kroneberg, 1875). Both sexes of $M$. marginatus and the male of $P$. flavescens are illustrated. The distribution of both species and the current state of knowledge of the Pakistani jumping spiders are discussed.

РЕЗЮМЕ. В настоящая работа приводятся две новые находки пауков для фауны Пакистана: Plexippoides flavescens (O. Pickard-Cambridge, 1872) и Menemerus marginatus (Kroneberg, 1875). Проиллюстрированы оба пола $M$. marginatus и самец $P$. flavescens. Кратко обсуждаются распространение обоих видов и уровень изученности пакистанских пауков-скакунчиков.

\section{Introduction}

The spider fauna of Pakistan is studied insufficiently. The only available checklist by Siliwal \& Molur [2007] includes 138 species, of which 37 are members of the family Salticidae (jumping spiders), but also misses some records: e.g., Heliophanus curvidens (O. Pickard-Cambridge, 1872) [Wesołowska, 1986]. For Turkey, which has about the same territory as Pakistan and similarly diverse landscapes, 110 species of the family Salticidae are listed [Bayram et al. 2014; Coşar, 2014]. This comparison alone shows how poorly the salticid fauna of Pakistan is yet studied.

In the present paper we report on two species of the jumping spiders, Menemerus marginatus (Kroneberg, 1875) and Plexippoides flavescens (O. Pickard-Cambridge, 1872) as new records for the spider fauna of
Pakistan. Both species were found in the vicinity of Turbat, Balochistan Province.

\section{Material and Methods}

Presented photographs of the copulatory organs were taken by the third author using a Canon EOS 400 connected to a Nikon SMZ 1000 stereomicroscope, photographs of the habitus were taken with the Canon EOS 400 plus close-up lens (Sigma 105, 1:2,8 plus spacer rings). The nomenclature follows the World Spider Catalog [2014]. Specimens were identified using the works by Logunov \& Zamanpoore [2005], Rakov \& Logunov [1997] and Wesołowska [1996]. The specimens of $M$. marginatus are deposited in the private collection of the second author (PCMF); the male of P. flavescens is deposited in the collection of the Manchester Museum, University of Manchester, Manchester, UK (MMUM, Dr. D.V. Logunov).

\section{Survey of Species}

Plexippoides flavescens (O. Pickard-Cambridge, 1872) Figs 1-2.

MATERIAL. PAKISTAN: $1 \sigma^{7}$ (MMUM), Balochistan Prov., near Turbat $\left(26^{\circ} 01^{\prime} \mathrm{N}\right.$ : $\left.63^{\circ} 03^{\prime} \mathrm{E}\right), 140 \mathrm{~m}$ a.s.1., on stones, April 2010, I.N. Mohamed.

COMMENTS. Both sexes of this species were described by Wesołowska [1996] and Prószyński [2003: sub $P$. arabicus $]$. Additional figures of the copulatory organs can be found in Logunov \& Zamanpoore [2005]; these authors also synonymized Plexipppoides stahrmuehleri (Roewer, 1955) with P. flavescens.

$P$. flavescens is widespread from the Near East to Central Asia and has been described under different 


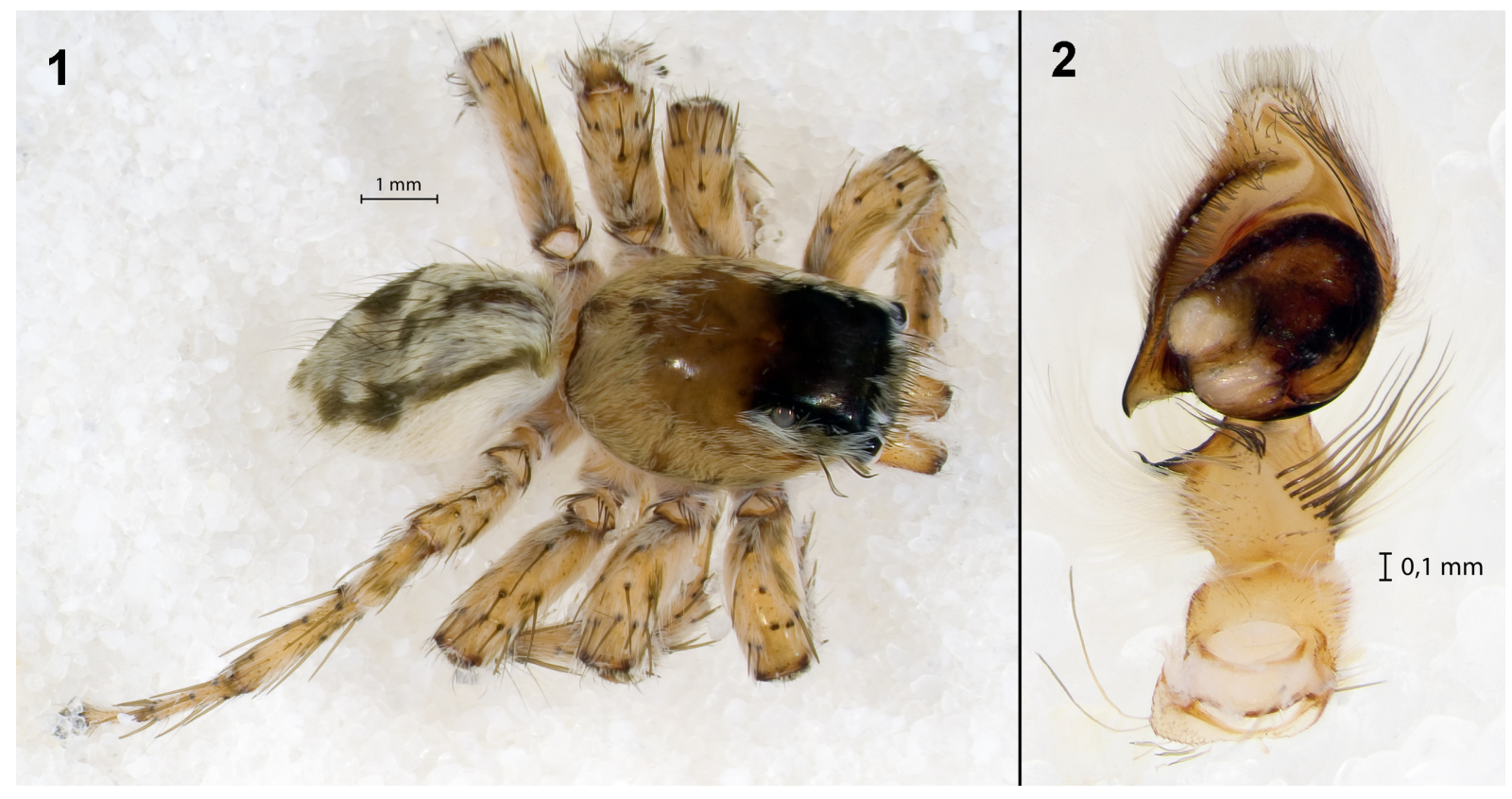

Figs 1-2. Plexippoides flavescens (O. Pickard-Cambridge, 1872): 1 - male, dorsal view; 2 - male palp, ventral view.

Рис. 1-2. Plexippoides flavescens (O. Pickard-Cambridge, 1872): 1 - самец, вид сверху; 2 - пальпа самца, вид снизу.

names from several localities [Logunov, Zamanpoore, 2005]. This species was also recorded from Europe (Greece) by Deltshev \& Paraschi [1990]. However, the latter record was considered doubtful by Metzner [1999] who also suspected that the Greek specimens should actually belong to Plexippoides gestroi (Dalmas, 1920). For a complete list of taxonomic sources see WSC [2014], for the arguments regarding synonymy see Wesołowska [1996] and Logunov \& Zamanpoore [2005]. The specimen presented in this work was collected from the stony ground together with the specimens of $M$. marginatus reported below.

Here we present digital photographs of the general appearance and the male palp of $P$. flavescens for the first time (Figs 1-2).

Menemerus marginatus (Kroneberg, 1875) Figs 3-6.

MATERIAL. PAKISTAN: $2 \sigma^{\top} \sigma^{\top}, 1$ (PCMF), Balochistan Prov., near Turbat $\left(26^{\circ} 01^{\prime} \mathrm{N}\right.$ : $\left.63^{\circ} 03^{\prime} \mathrm{E}\right), 140 \mathrm{~m}$ a.s.l., on stones, April 2010, I.N. Mohamed.

COMMENTS. Both sexes of this species were described by Wesolowska [1996] and Wesolowska \& van Harten [2011] (with additional photographs of both sexes).

M. marginatus is the only species of the genus Menemerus occuring in Middle Asia [Rakov, Logunov 1997] and was recorded from Afghanistan [Logunov, Zamanpoore 2005]. Menemerus raji Dyal, 1935, the only species of this genus known from Pakistan according to Siliwal \& Molur [2007], was reported by Wesołowska \& Freudenschuss [2012] to be nomen dubium. The latter authors also described a new species, Menemerus nigli Wesołowska et Freudenschuss
2012, from a single male from the same locality where $M$. marginatus was collected. The male of $M$. marginatus differs from that of $M$. nigli by the curved tibial apophysis which is broadened at its base and by the straight embolus (Fig. 4).

\section{Discussion}

The state of faunistic and taxonomic knowledge of the Pakistani Salticidae is complicated. Some of the earlier described species require a revision and confirmation upon reference to the pertinent material, because the published information and drawings are inadequate for reliable identification. Some of the earlier described species were taxonomically misplaced [Logunov et al. 2011]. For instance, none of the four species of Marpissa C.L. Koch, 1846 described by Butt \& Beg [2000] actually belongs to this genus. Furthermore, these species names will inevitably become nomina dubia, as their type material was lost (Logunov, pers. comm.). Most of the species described by Dyal [1935] from Pakistan have never been collected and/or described again [WSC 2014], so their taxonomic status also remains unclear. Further studies are essential to gain a better knowledge of the spider fauna of Pakistan.

ACKNOWLEDGEMENTS. We are very thankful to D.V. Logunov (Manchester, UK) for his help with relevant literature, species identifications and comments on the state of knowledge of the Salticidae of Pakistan. We are also very thankful to R. Breitling (Manchester, UK) for his valuable comments on the earlier draft and for linguistic help. 


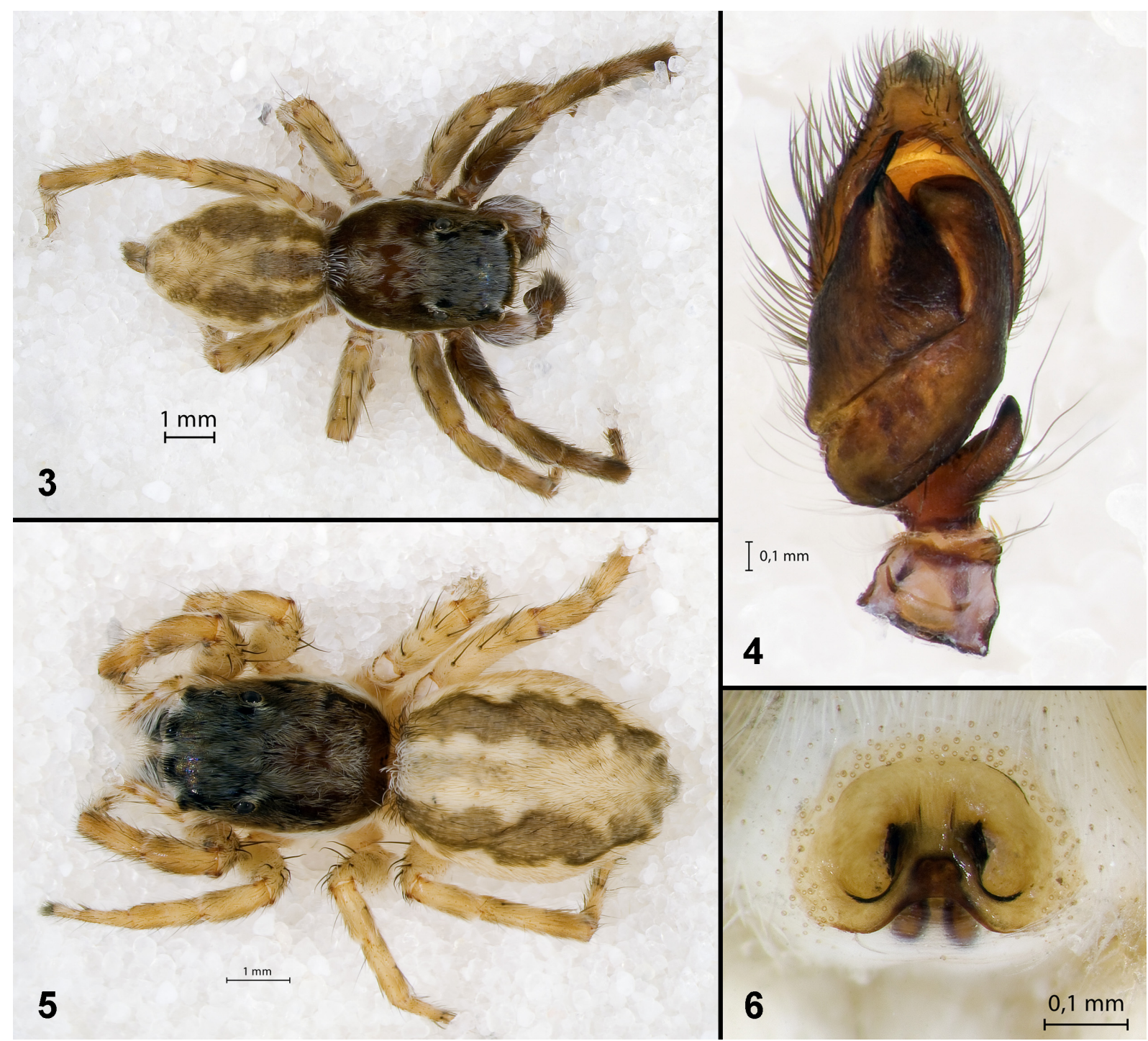

Figs 3-6. Menemerus marginatus (Kroneberg, 1875): 3 - male, dorsal view; 4 - male palp, ventral view; 5 - female, dorsal view; 6 epigyne, ventral view.

Рис. 3-6. Menemerus marginatus (Kroneberg, 1875): 3 - самец, вид сверху; 4 - пальпа самца, вид снизу; 5 - самка, вид сверху; 6 - эпигина, вид снизу.

\section{References}

Bayram A., Kunt K.B., Dan man T. 2014. The Checklist of the Spiders of Turkey. Version 2014; online at: http://www. kazimcapaci.com/spidersofturkey.htm (assessed on 05.11.2014).

Butt A., Beg M.A. 2000. Some new species of Marpissa (Salticidae) spiders from Pakistan // Pakistan J. Zool. Vol.32. No.1. P.75-79.

Co ar . 2014. Four new records for the spider fauna of Turkey (Araneae: Salticidae) // Turkish J. Zool. Vol.38. P.1-4.

Deltshev C., Paraschi L. 1990. A contribution to the study of spiders (Araneae: Dysderidae, Salticidae, Agelenidae) in Greece, with a description of new species (Malthonica spinipalpis Deltshev sp. n., Agelenidae) // Biol. Gallo-Hell. Vol.17. No.1. P.3-12.

Dyal S. 1935. Fauna of Lahore. 4. Spiders of Lahore // Bull. Dep. Zool. Punjab Univ. No.1. P.119-252.

Logunov D.V., Ballarin F., Marusik Yu.M. 2011. New faunistic records of the jumping and crab spiders of Karakoram, Paki- stan (Aranei: Philodromidae, Salticidae and Thomisidae // Arthropoda Selecta. Vol.20. No.3. P.233-240.

Logunov D.V., Zamanpoore M. 2005. Salticidae (Araneae) of Afghanistan: an annotated check-list, with descriptions of four new species and three new synonymies // Bull. Br. arachnol. Soc. Vol.13. Pt.6. P.217-232.

Metzner H. 1999. Die Springspinnen (Araneae, Salticidae) Griechenlands // Andrias. Bd.14. S.1-279.

Prószyński J. 2003. Salticidae (Araneae) of the Levant // Ann. Zool. Warszawa. T.53. P.1-180.

Rakov S.Yu., Logunov D.V. 2007. Taxonomic notes on the genus Menemerus Simon, 1868 in the fauna of Middle Asia (Araneae, Salticidae) // M. Żabka (ed.). Proceedings of the 16th European Colloquium of Arachnology, Siedlce. P.271-279.

Siliwal M., Molur S. 2007. Checklist of Spiders (Arachnida; Araneae) of South Asia including the 2006 update of Indian Spider Checklist // Zoos' Print Journal. Vol.22. No.2. P.2551-2597.

Wesołowska W. 1986. A revision of the genus Heliophanus C.L. Koch, 1833 (Aranei: Salticidae) // Annal. Zool. Vol.40. P.1254. 
Wesołowska W. 1996. New data on the jumping spiders of Turkmenistan (Aranei Salticidae) // Arthropoda Selecta Vol.5. No.1. P.17-53.

Wesołowska W., Freudenschuss M. 2012. A new species of Menemerus from Pakistan (Araneae, Salticidae) // Genus. Vol.23. No.3. P.449-453.
Wesołowska W., van Harten A. 2011. Order Araneae, family Salticidae. Additions and the description of a new species // Arthropod fauna of the UAE. No.4. P.23-28.

WSC 2014. World Spider Catalog. Natural History Museum Bern, version 15.5; online at: http://wsc.nmbe.ch (accessed on $05.11 .2014)$.

Responsible editor D.V. Logunov 